\title{
Evaluation of antioxidants stability by thermal analysis and its protective effect in heated edible vegetable oil
}

\author{
Avaliação da estabilidade de antioxidantes por análise térmica e seu efeito protetor em óleo vegetal aquecido
}

\author{
Seme Youssef REDA ${ }^{1 *}$
}

\begin{abstract}
In this work, through the use of thermal analysis techniques, the thermal stabilities of some antioxidants were investigated, in order to evaluate their resistance to thermal oxidation in oils, by heating canola vegetable oil, and to suggest that antioxidants would be more appropriate to increase the resistance of vegetable oils in the thermal degradation process in frying. The techniques used were: Thermal Gravimetric (TG) and Differential Scanning Calorimetry (DSC) analyses, as well as an allusion to a possible protective action of the vegetable oils, based on the thermal oxidation of canola vegetable oil in the laboratory under constant heating at $180^{\circ} \mathrm{C} / 8$ hours for 10 days. The studied antioxidants were: ascorbic acid, sorbic acid, citric acid, sodium erythorbate, BHT (3,5-di-tert-butyl-4-hydroxytoluene), BHA (2, 3-tert-butyl-4-methoxyphenol), TBHQ (tertiary butyl hydroquinone), PG (propyl gallate) - described as antioxidants by ANVISA and the FDA; and also the phytic acid antioxidant and the SAIB (sucrose acetate isobutyrate) additive, which is used in the food industry, in order to test its behavior as an antioxidant in vegetable oil. The following antioxidants: citric acid, sodium erythorbate, BHA, BHT, TBHQ and sorbic acid decompose at temperatures below $180^{\circ} \mathrm{C}$, and therefore, have little protective action in vegetable oils undergoing frying processes. The antioxidants below: phytic acid, ascorbic acid and PG, are the most resistant and begin their decomposition processes at temperatures between 180 and $200{ }^{\circ} \mathrm{C}$. The thermal analytical techniques have also shown that the SAIB antioxidant is the most resistant to oxidative action, and it can be a useful choice in the thermal decomposition prevention of edible oils, improving stability regarding oxidative processes.

Keywords: thermal analysis; thermal oxidization; thermal decomposition; food additives; antioxidants.
\end{abstract}

\section{Resumo}

Neste trabalho, utilizando as técnicas de análise térmica foram investigadas as estabilidades térmicas de alguns antioxidantes com o objetivo de avaliar sua resistência com relação a termo oxidação em óleos comestíveis, por meio do aquecimento do óleo de canola e sugerir quais seriam mais adequados para aumentar a resistência de óleos vegetais frente a processos de degradação térmica em frituras. As técnicas utilizadas foram a Termogravimetria (TG) e Calorimetria Exploratória Diferencial (DSC) e uma alusão da possível ação protetora em óleos vegetais, tomando como base, o estudo específico da termo-oxidação do óleo de canola realizado em laboratório, sob aquecimento constante em $180^{\circ} \mathrm{C} / 8$ hours, por 10 dias. Os antioxidantes estudados foram o ácido ascórbico, ácido sórbico, ácido cítrico, eritorbato de sódio, BHT (3,5-di-terc-butil-4-hidroxitolueno), BHA (2, 3-terc-butil-4-metoxifenol), TBHQ (terc-butilhidroquinona), PG (galato de propila), descritos como antioxidantes pela ANVISA e pela FDA e também o antioxidante ácido fítico e o aditivo SAIB (isobutirato acetato de sacarose) utilizado na indústria de alimentos, para testar seu comportamento como antioxidante em óleo vegetal. Os antioxidantes ácido cítrico, eritorbato de sódio, BHA, BHT, TBHQ e ácido sórbico se decompõem em temperaturas inferiores a $180{ }^{\circ} \mathrm{C}$, em que teriam pouca ação protetora em óleos vegetais submetidos a processos de frituras. Os antioxidantes ácidos fítico, ascórbico e PG são mais resistentes e iniciam o processo de decomposição no intervalo de temperatura entre $180-200^{\circ} \mathrm{C}$. As técnicas termoanalíticas mostraram também que o antioxidante SAIB é mais resistente à ação oxidativa e pode ser uma escolha para ser usado na prevenção da decomposição térmica de óleos comestíveis, melhorando a estabilidade em face de processos oxidativos.

Palavras-chave: análise térmica; termo-oxidação; decomposição térmica; aditivos em alimentos; antioxidantes.

\section{Introduction}

Cooking was a breakthrough for mankind that improved the flavor digestibility and quality of food. Heat treatment is an operation widely used in food processing. As heat-processed foods are much appreciated, analytical studies that can assess the changes caused by heating have been demanded from researchers (LAMBELET et al., 2003). Some foods like fats and oils, when heated, suffer thermal oxidation and produce compounds such as peroxides. The peroxides turn into aldehydes, ketones, epoxides, dimers and polymers, undermining the quality of food. In order to minimize such effects, the food industry makes use the antioxidants (LITWINIENKO; KASPRZSYCKA-GUTTMAN; JAMANEK, 1999).

There has been considerable interest in the field of antioxidants in recent years and these efforts have led to a better understanding of the mechanisms involved and of the application areas in food. In addition, efforts are underway for devising better and more uniform methodologies for the evaluation and measurement of the oxidation and efficacy of antioxidants (SHAHIDI, 2008).

Received 21/9/2009

Accepted 18/1/2010 (004391)

${ }^{1}$ Engenharia de Alimentos, Universidade Estadual de Ponta Grossa - UEPG, Campus Uvaranas, Av. General Carlos Cavalcanti, 4748, CEP 84030-900, Ponta Grossa - PR, Brasil,E-mail:sreda2007@gmail.com

${ }^{*}$ Corresponding author 
Antioxidants are additives that delay the onset of oxidative changes in food (BRASIL, 1997). Thus, they contribute to food preservation, prevent changes in flavor, and slow rancidity and discoloration processes (BITAR et al., 2008). Several antioxidants, such as citric acid, BHA (2 and 3-tert-butyl-4methoxyphenol), TBHQ (tertiary butyl hydroquinone), BHT (3.5-di-tert-butyl-4-hydroxytoluene) and propyl gallate - PG (3.4.5-trihydroxybenzoate propyl), are used in food preservation as stocked vegetable oils (KIM et al., 2009). The following antioxidants: BHA, TBHQ, BHT, PG, as well as ascorbic acid, sorbic acid and citric acid, are listed in the FDA (U. S. FOOD..., 2009) as authorized food additives. Also, ascorbic acid, sodium ascorbate, calcium ascorbate, potassium ascorbate, erythorbic acid, isoascorbic acid, sodium erythorbate, isoascorbate sodium, lecithin, sodium lactate, citric acid, calcium citrate, calcium citrate tri-acid, citric acid esters, fatty acids with glycerol and glucose oxidase (Aspergillus niger), are allowed as antioxidants in food by ANVISA (BRASIL, 1999a).

Phytic acid, due to its ability to chelate iron and inhibit the emergence of hydroxyl radicals, is used as antioxidant and to prevent discoloration and extend the average life of foods (FILGUEIRAS et al., 2009).

The food industry uses sucrose acetate isobutyrate (SAIB) as an additive in beverages. SAIB is a mixture of esters of sucrose with a composition approximating the name sucrose diacetate hexaisobutyrate (TAHERIAN; RAMASWAMY, 2007). Sucrose acetate isobutyrate is used as a density-broker brominated vegetable oil, exclusively for non-alcoholic beverages to $15 \mathrm{mg} \cdot \mathrm{kg}^{-1}$ (BRASIL, 1999b). So, using SAIB as an antioxidant in vegetable oils would not be technologically difficult, since the food industry already uses it as an additive in beverages. In its mechanism of action, it stabilizes the free radical through electron delocalization in the aromatic ring (resonance effect) and so, it ruthlessly spreads the oxidative free radical reactions in the middle. Its mechanism of action slows the rate of formation of the chain initiation of lipid radicals to destroy the formed hydroperoxides (SILVERSTEIN; WEBSTER, 2000; FOTI; AMORATI, 2009).

The knowledge of thermal stability of antioxidants is very important in food preservation. Thermogravimetric techniques continuously measure the mass of a sample as it is heated or cooled at a controlled rate, or is held at a particular temperature for a period of time. It is useful for monitoring processes that involve changes in the mass of food or food component. To evaluate the various types of processing and storage conditions that some food might normally experience, DSC techniques rely on changes in the heat absorbed or released by a material as its temperature is varied at a controlled rate. These changes occur when components within some food undergo some type of phase transition or chemical reaction (oxidation, hydrolysis) (ROOS, 2003).

In edible oils, the choice of antioxidant must be aimed at the preservation of unsaturated fatty acids to increase the stability to thermal degradation, which usually happens between 150 and $220{ }^{\circ} \mathrm{C}$. However, the presence of high concentrations of unsaturated fatty acids in vegetable oils requires greater thermal stability of the antioxidant (YILMAZ; KARAKAYA, 2009).
Several studies have been developed using thermal analysis techniques to evaluate the effect of antioxidant addition in food protection against oxidation (LITWINIENKO;KASPRZSYCKAGUTTMAN; JAMANEK, 1999; VECCHIO et al., 2008).

The present study investigated the thermal stability of the following antioxidants: ascorbic acid, sorbic acid, citric acid, sodium erythorbate, BHA, BHT, TBHQ, PG linked to the FDA and ANVISA, as well as phytic acid and SAIB additive, to test it as an antioxidant in vegetable oil in an isolated system, using the thermogravimetry (TG) and differential scanning calorimetry (DSC) techniques, and its protective action in vegetable oils undergoing the process of heating, taking as standard the study of canola oil subjected to heating.

\section{Materials and methods}

The following antioxidants were used in this study: phytic acid [(myo-inositol hexakis (dihydrogen phosphate)], tert-butyl hydroquinone (TBHQ), citric acid, 2 and 3-tertbutyl-4-hydroxyanisole and 2,3-tert-butyl-4-methoxyphenol (BHA) 3,5-di-tert-butyl-4-hidroxilueno or 2,6-di-tert-butyl4-methyl-phenol or 2,6-di-tert-butyl-p-cresol (BHT), sodium erythorbate (monohydrate of $\mathrm{D}$-isoascorbate sodium or -lactone), 3.4.5-trihydroxybenzoate propyl or propyl- $\delta$ acid-Derythro-hex-2-enoic-gallate (PG), sorbic acid or acid (2E, 4E)hexa-2.4-dienoic acid (SBA), acid-L-ascorbic acid and sucrose acetate isobutyrate (SAIB).

\subsection{Physicochemical characterization of canola vegetable oil}

The determination of iodine value and free acidity was performed by hydrogen nuclear magnetic resonance $\left({ }^{1} \mathrm{H}-\mathrm{NMR}\right)$ (CARNEIRO; REDA; CARNEIRO, 2005; REDA; CARNEIRO, 2006). (2002).

The peroxide index was performed according to Moretto et al

\subsection{Thermal analysis}

The thermo analytical curves were obtained in module, simultaneously, at TG/DSC equipment TA - Instruments, Model 2960, operating under the following conditions: heating rate of $20^{\circ} \mathrm{C} /$ minute in an atmosphere of synthetic air flow of $70 \mathrm{~mL} /$ minute in an alumina crucible $\left(\alpha-\mathrm{Al}_{2} \mathrm{O}_{3}\right)$ containing approximately 10 to $20 \mathrm{mg}$ of sample at a temperature range of $25-600{ }^{\circ} \mathrm{C}$.

\subsection{Hydrogen nuclear magnetic resonance}

About 10 to $20 \mathrm{mg}$ of canola vegetable oil was dissolved in $0.7 \mathrm{~mL}$ of $\mathrm{CDCl}_{3}$ and its NMR spectrum was recorded on spectrometer Varian Mercury-300 MHz operating on the FT mode at room temperature.

\subsection{Thermal stress of canola vegetable oil (Brassica campestris)}

Refined canola vegetable oil was subjected to continuous heating, 8 hours daily, for 10 consecutive days. The amount of 
$200 \mathrm{~mL}$ of vegetable oil was heated in a glass refractory heated refractory ceramic ring with exposure resistant of $180^{\circ} \mathrm{C}$.

\section{Results and discussion}

Table 1 shows the results of the physical chemical determinations for canola vegetable oil in natura and under heating. The peroxide index was $1.90 \mathrm{mEq} \cdot \mathrm{kg}^{-1}$ and it remained within the range established by legislation (BRASIL, 2005). As the peroxide value measures the degree of oxidation (FENNEMA, 2000), there was no change with respect to this result for the canola oil in natura. Another important effect observed was the reduction of the levels of peroxides after 16 hours of heating. It was consistent with the characteristic chemistry of peroxides produced in the thermal oxidative actions, which are very unstable and degrade easily, being transformed into dimers and polymers (LI; LAROCK, 2003). The degree of instauration of the vegetable oil also diminished gradually with the progression of heating and it was demonstrated through the iodine value data. The progressive increase of free acidity was also an important detected result. It is characteristic of heating processes when free radicals are being generated (RAMALHO; JORGE, 2006). After 80 hours of heating, the vegetable oil polymerized entirely due to the large number of polymers formed during the heating process.

It is important for vegetable oils that the value of peroxide index remains within the limits specified not to cause any major changes in food quality. Indeed, when the oil is heating in the frying process, a complex series of reaction produces many degradation compounds. In the course of the reactions, the functional qualities of sensory and nutritional properties are modified. Than, when the food is deep in hot oil, it is exposed to water from the food itself, oxygen and the high temperature at which the process occurs, resulting in thermal changes such as isomerisation and fission reactions, producing aldehydes and ketones to form many degradation products such as epoxides and peroxides (FARIA et al., 2002).

Figure 1 shows the TGA/DSC of phytic acid. It was observed a significant weight loss at $160^{\circ} \mathrm{C}$ in the DSC curve. A change in the physical state, by the endothermic peak, was observed at that temperature. This demonstrates that the compound underwent decomposition; phytic acid is not suitable as an antioxidant in

Table 1. Physicochemical analysis of canola oil by heating row ( 0 hour) and under heating.

\begin{tabular}{cccc}
\hline $\begin{array}{c}\text { Time heating } \\
\text { (hours })\end{array}$ & $\begin{array}{c}\text { Peroxide } \\
\text { index }\end{array}$ & $\begin{array}{c}\text { Free acidity } \\
\left({ }^{1} \mathrm{H}-\mathrm{NMR}\right)\end{array}$ & $\begin{array}{c}\text { Iodine value } \\
\left({ }^{1} \mathrm{H}-\mathrm{NMR}\right)\end{array}$ \\
\hline 0 hour & 1,90 & 0,13 & 114,34 \\
8 hours & 5,70 & 0,27 & 102,41 \\
16 hours & 7,70 & 0,48 & 96,06 \\
24 hours & 3,80 & 0,67 & 85,08 \\
32 hours & 3,10 & 0,82 & 77,20 \\
40 hours & 3,80 & 0,96 & 67,88 \\
48 hours & 1,90 & 1,24 & 60,24 \\
56 hours & 1,94 & 1,51 & 56,53 \\
64 hours & 1,90 & 1,64 & 53,94 \\
72 hours & 1,90 & 1,63 & 50,76 \\
80 hours & Polymerization & Polymerization & Polymerization \\
\hline
\end{tabular}

vegetable oils in frying processes, because it decomposes at temperatures below $180-200{ }^{\circ} \mathrm{C}$.

Figure 2 shows the TGA/DSC of citric acid. The analysis of the DSC curve shows that the citric acid changes its composition at around $160{ }^{\circ} \mathrm{C}$, characterized by a strong endothermic peak at that temperature. At the same time, it can be observed, in the TG curve, a start in weight loss at around $160{ }^{\circ} \mathrm{C}$, culminating at around $220^{\circ} \mathrm{C}$. The two peaks revealed by the DSC curve refer to a change in the physical state, indicating a process of decomposition, making it unsuitable as a prophylactic antioxidant in processes that require protection of food free radical attack caused by high temperatures.

Figure 3 shows the TGA/DSC BHA. It is observed that the decomposition of the antioxidant starts at around $120^{\circ} \mathrm{C}$. The DSC curve shows an evident endothermic peak at around $60{ }^{\circ} \mathrm{C}$ indicating the melting point of the compound, which is volatile in the temperature range of $100-240^{\circ} \mathrm{C}$. BHA does not provide adequate protection, for example, to vegetable oils at temperatures that food is exposed to in frying processes (180-200 $\left.{ }^{\circ} \mathrm{C}\right)$.

The TGA/DSC (Figure 4) shows the thermal behavior of the antioxidant BHT, whose decomposition begins at around $120^{\circ} \mathrm{C}$, similarly to BHA. The DSC curve shows an endothermic peak at

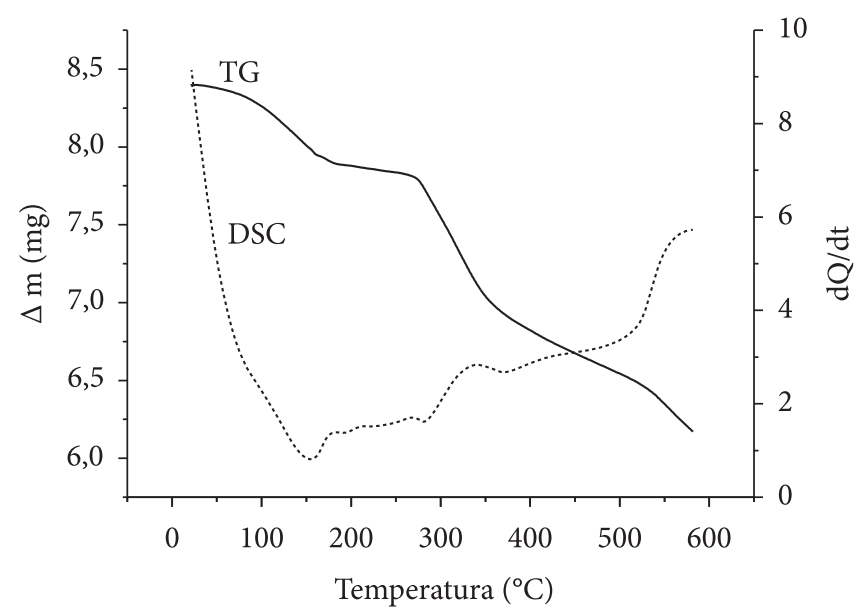

Figure 1. TG and DSC curves of the phytic acid antioxidant.

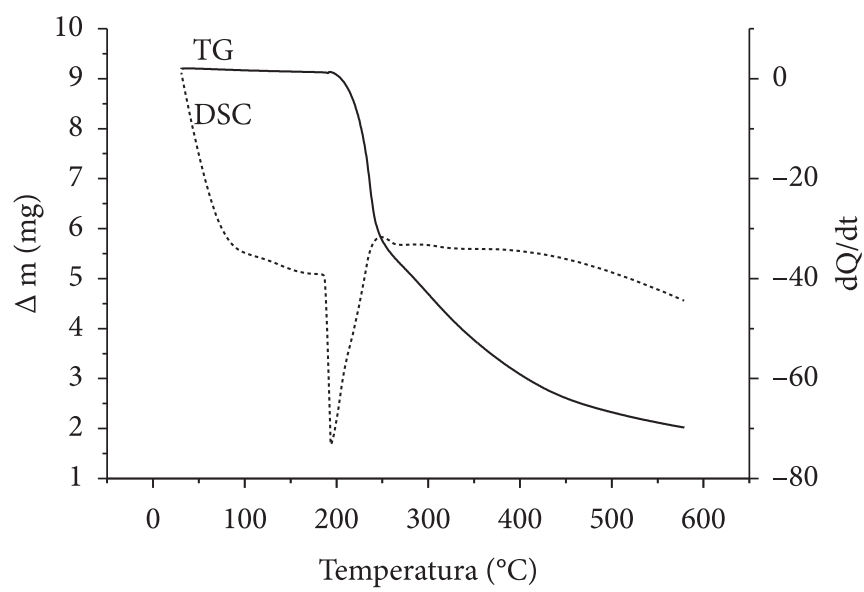

Figure 2. TG and DSC curves of the citric acid antioxidant. 
around $70^{\circ} \mathrm{C}$, corresponding to its melting point. On the other hand, Figure 5 shows the TGA/DSC of sodium erythorbate, where changes in the antioxidant are observed at $170^{\circ} \mathrm{C}$ and $340^{\circ} \mathrm{C}$. The compound does not keep its structure intact in the temperature range between 170 and $200{ }^{\circ} \mathrm{C}$, with major changes right away.

Figure 6 shows the TGA/DSC of propyl gallate (PG). An endothermic peak is observed at $150{ }^{\circ} \mathrm{C}$, corresponding to its

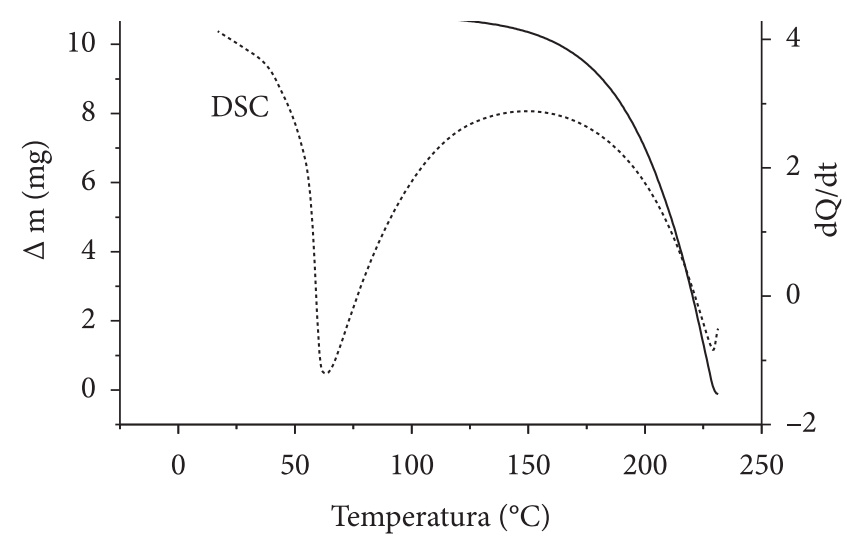

Figure 3. TG and DSC curves of the BHA antioxidant.

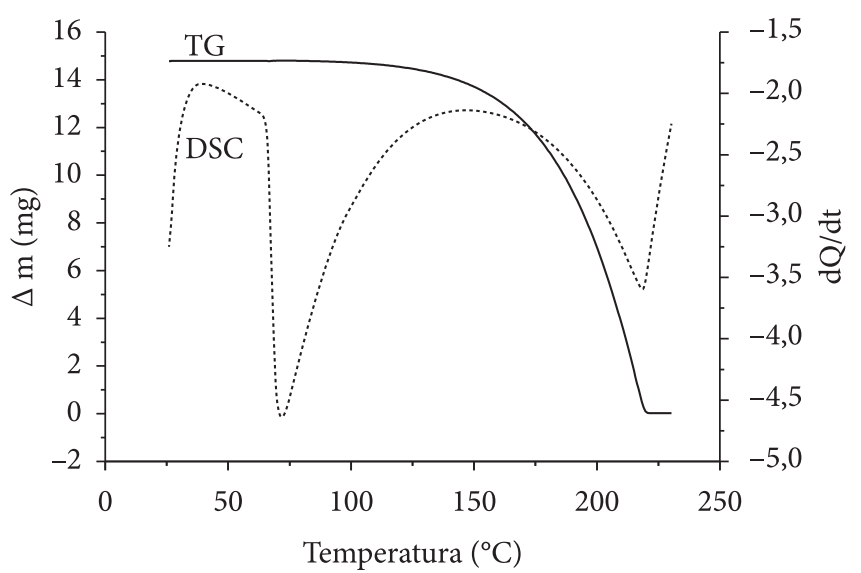

Figure 4. TG and DSC curves of the BHT antioxidant.

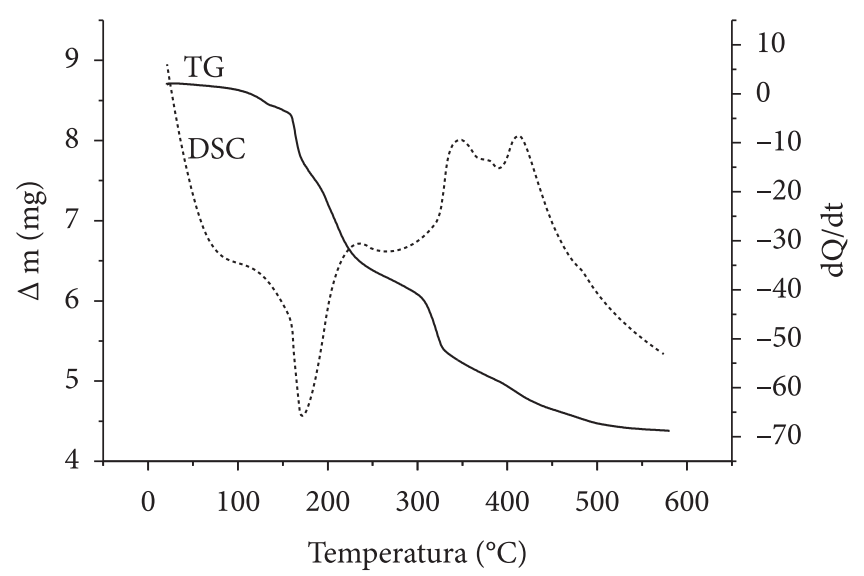

Figure 5. TG and DSC curves of the sodium erythorbate antioxidant. melting point and an exothermic peak at around $350{ }^{\circ} \mathrm{C}$, also corresponding to its oxidation. The compound is stable up to $220^{\circ} \mathrm{C}$. Propyl Gallate is indicated as prophylactic in thermal oxidative processes due to frying. However, in Figure 7, which shows the TGA/DSC of sorbic acid, it is observed that the decomposition temperature of this antioxidant is between $140{ }^{\circ} \mathrm{C}$ (melting point) and $200{ }^{\circ} \mathrm{C}$, temperature at which there is an overlap between the TG and DSC curves, indicating that the compound begins its melting and decomposition simultaneously.

Ascorbic acid (Figure 8) shows that the melting temperature and decomposition of antioxidant starts at around $190^{\circ} \mathrm{C}$.

Anyway, Figure 9 shows the TGA/DSC of SAIB (sucrose acetate isobutyrate), where it can be seen, in the DSC curve, an inflection point at around $90^{\circ} \mathrm{C}$ and another at around $150{ }^{\circ} \mathrm{C}$. As the TG curve shows no weight loss at these temperatures, these points indicate loss of water. This observation was also reported by Freire, Figueiredo and Ferrão (1999), when studying olive oil. The analysis of the TG curve shows that the compound has a single mass loss that starts at $248^{\circ} \mathrm{C}$ and ends at $340{ }^{\circ} \mathrm{C}$. In the DSC curve, there is a very strong exothermic reaction that causes deformation of the DSC peak and the deformation in the TG curve (adding the oven heat and the heat generated by burning of the sample). Thermal stability up to $250{ }^{\circ} \mathrm{C}$ was

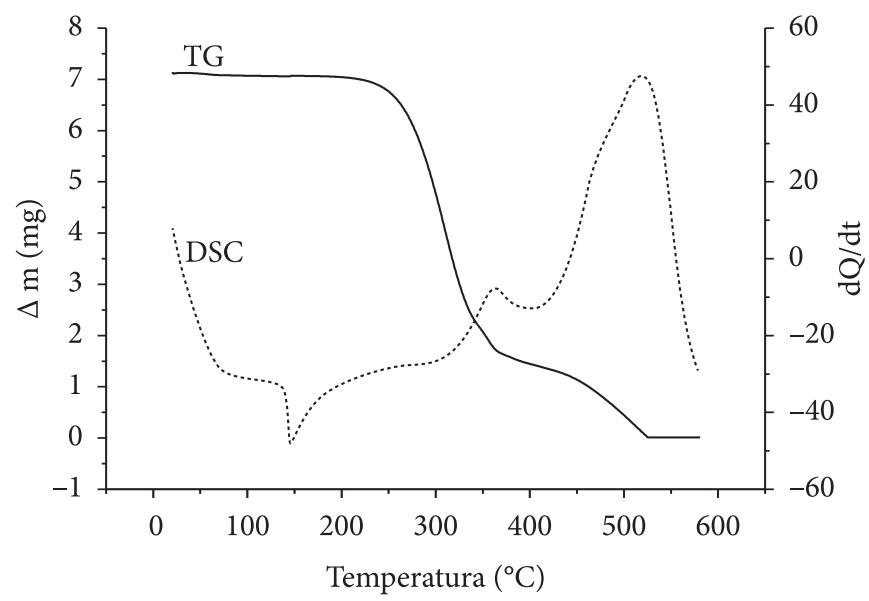

Figure 6. TG and DSC curves of the propyl gallate antioxidant.

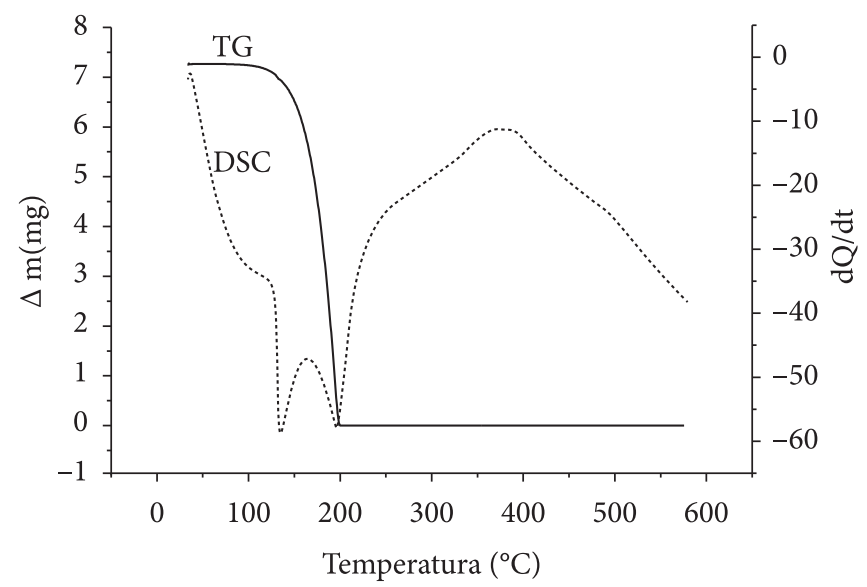

Figure 7. TG and DSC curves of the acid sorbic antioxidant. 
the best value for the studied antioxidants, which can prevent or minimize most effectively the thermal-oxidative damage.

Figure 10 shows the TGA/DSC TBHQ. The curve shows that the decomposition of the antioxidant initiates at $120^{\circ} \mathrm{C}$, with total decomposition at $210{ }^{\circ} \mathrm{C}$. Therefore, it offers little protection to vegetable oils undergoing a long process of heating.

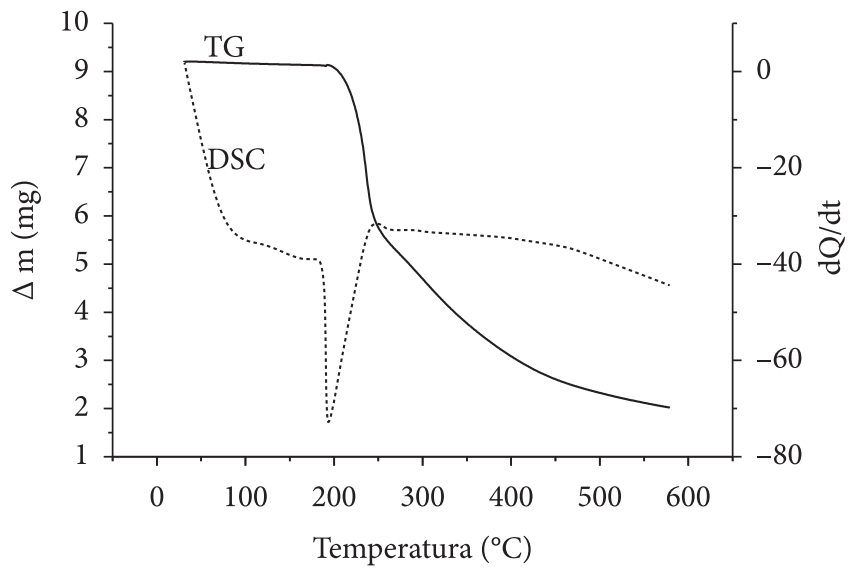

Figure 8. TG and DSC curves of the ascorbic acid antioxidant.

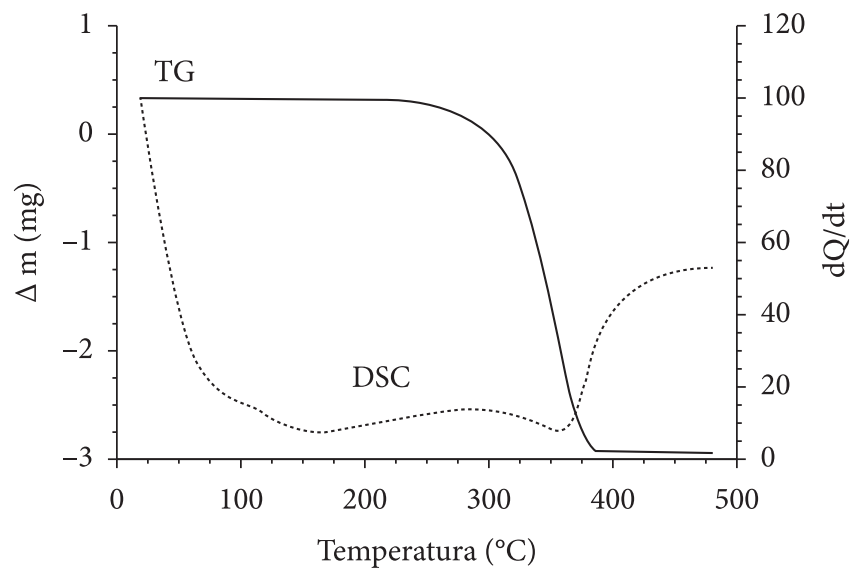

Figure 9. TG and DSC curves of the SAIB antioxidant.

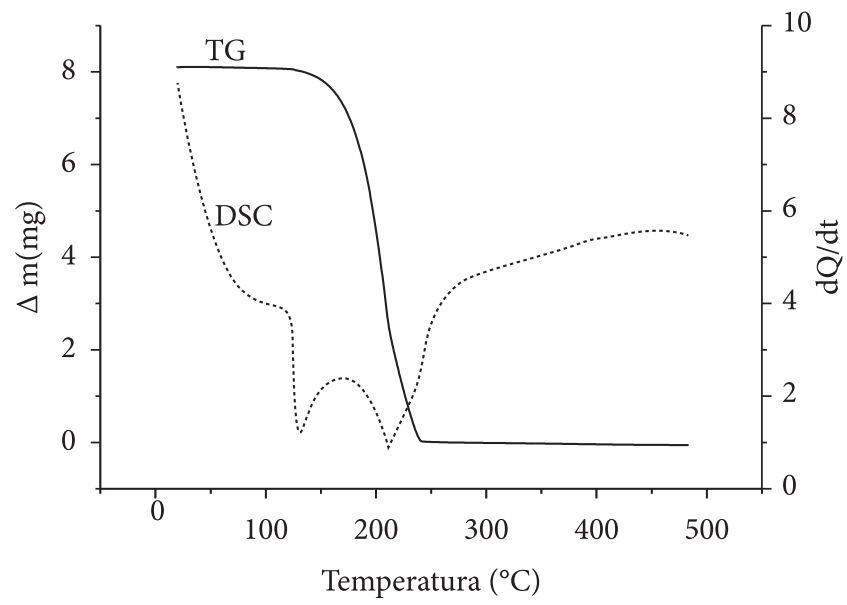

Figure 10. TG and DSC curves of the TBHQ antioxidant.

\section{Conclusions}

The analysis of canola oil showed that upon heating deteriorates gradually increased by the same antioxidant citric acid. The results obtained through thermal analysis clearly showed the thermal behavior of the antioxidants studied. Citric acid, BHA, BHT, TBHQ, sodium erythorbate and sorbic acid antioxidants decompose or start their decomposition at temperatures below $180^{\circ} \mathrm{C}$, offering little protection to heated vegetable oils. Phytic acid, ascorbic acid and yield compounds are stronger, starting to decompose between 180 and $200{ }^{\circ} \mathrm{C}$, and are, therefore, more likely to offer resistance to vegetable oils in the face of thermal oxidative processes. However, the antioxidants that showed better resistance levels were SAIB and $\mathrm{PG}$, starting their decomposition at temperatures above $200{ }^{\circ} \mathrm{C}$ and $220^{\circ} \mathrm{C}$, respectively. Propyl Gallate is indicated as prophylactic in thermal oxidative processes due to frying. From these results, it is expected that SAIB can be an antioxidant option to edible oils.

\section{References}

BITAR, A. et al. Sensory Thresholds of Selected Phenolic Constituents from Thyme and their Antioxidant Potential in Sunflower Oil. Journal of the American Oil Chemists Society, v. 85, p. 641-646, 2008.

BRASIL. Ministério da Sáude. Agência Nacional de Vigilância Sanitária - ANVISA. Resolução nº 270, de 22 de setembro de 2005. Aprova o regulamento técnico para óleos vegetais, gorduras vegetais e creme vegetal.Diário Oficial da República Federativa do Brasil, Poder Executivo, Brasília, DF, 23 set. 2005.

BRASIL. Ministério da Sáude. Agência Nacional de Vigilância Sanitária - ANVISA. Portaria n 540, de 27 de outubro de 1997. Aprova o Regulamento Técnico: Aditivos Alimentares - definições, classificação e emprego. Diário Oficial da República Federativa do Brasil, Brasília, DF, 28 out. 1997.

BRASIL. Ministério da Sáude. Agência Nacional de Vigilância Sanitária - ANVISA. Resolução no 386 de 5 de agosto de 1999a. Regulamento técnico sobre aditivos utilizados segundo as boas práticas de fabricação e suas funções. Diário Oficial da República Federativa do Brasil, Brasília, DF, 09 ago. 1999.

BRASIL. Ministério da Sáude. Agência Nacional de Vigilância Sanitária ANVISA. Resolução nº104, de 14 de maio de 1999b. Regulamento técnico sobre aditivos aromatizantes/aromas. Diário Oficial da República Federativa do Brasil, Brasília, DF, 17 maio 1999.

CARNEIRO, P. I. B.; REDA, S. Y.; CARNEIRO, E. B. B. ${ }^{1} \mathrm{H}$ NMR Characterization of Seed Oils from Rangpur Lime (Citrus limonia) and "Sicilian" Lemon (Citrus limon). Annals of Magnetic Resonance, v. 4, n. 3, p. 64-68, 2005.

FARIA, A. A. et al. Estudo da Estabilidade Térmica de Óleos e Gorduras Vegetais por TG/DTG e DTA. Eclética Química, v. 27, p. 111-119, 2002. http://dx.doi.org/10.1590/S0100-46702002000100010

FENNEMA, O. R. Química de los alimentos. 2. ed. Zaragoza: Acríbia, 2000.

FILGUEIRAS, C. T. et al. Avaliação da atividade antioxidante do ácido fítico de germe de milho. Química Nova, v. 32, n. 7, p . 1787-1791, 2009. http://dx.doi.org/10.1590/S0100-40422009000700020

FOTI, M. C.; AMORATI, R. Non-phenolic radical-trapping antioxidants. Journal of Pharmacy and Pharmacology, v. 61, n. 11, p. 1435-1448, 2009. PMid:19903368. http://dx.doi.org/10.1211/ jpp.61.11.0002 
FREIRE, F.; FIGUEIREDO, A.; FERRÃO, P. Thermal Analysis and Drying Kinetics of Olive Bagasse. Drying Tecnology, v. 17, n. 4, p. 895-907, 1999. http://dx.doi.org/10.1080/07373939908917577

KIM, J. I. et al. Kinetic Study of the Quenching Reaction of Singlet Oxygen by Common Synthetic Antioxidants (tert-Butylhydroxyanisol, tert-di-Butylhydroxytoluene, and tert-Butylhydroquinone) as Compared with $\alpha$-Tocopherol. Journal of Food Science, v. 74, n. 5, p. c363-c369, 2009. http://dx.doi. org/10.1111/j.1750-3841.2009.01160.x

LAMBELET, P. et al. Formation of Modified Fatty Acids and Oxyphytosterols during Refining of Low Erucid Acid Rapeseed Oil. Journal of Agricultural and Food Chemistry, v. 52, n. 15, p. 4284-4290, 2003. PMid:12848499. http://dx.doi.org/10.1021/ jf030091u

LI, F.; LAROCK, R. C. Synthesis, Structure and Properties of New Tung Oil - Styrene - Divinylbenzene Copolymers Prepared by Thermal Polimerization. Biomacromolecules, v. 4, p. 1018-1025, 2003. PMid:12857087. http://dx.doi.org/10.1021/bm034049j

LIT WINIENKO, G.; KASPRZSYCKA-GUTTMAN, T.; JAMANEK, D. DSC study of antioxidant properties of dihydroxyphenols. Thermochimica Acta, v. 331, p. 79-86, 1999. http://dx.doi.org/10.1016/S0040-6031(99)00058-1

MORETTO, E. et al. Introdução à Ciência de Alimentos. Florianópolis: UFSC, 2002.

RAMALHO, V. C.; JORGE, N. Antioxidants used in oils, fats and fatty foods. Química Nova, v. 29, n. 4, p. 755-760, 2006.

REDA, S. Y.; CARNEIRO, P. I. B. Parâmetros físico-químicos do óleo de milho in natura e sob aquecimento calculado pelo programa proteus RMN H1. Publicatio UEPG: Ciências Exatas e da Terra, Ciências Agrárias e Engenharias, v. 12, n. 2, p. 31-36, 2006.
ROOS, Y. H. Thermal analysis, state transitions and food quality. Journal of Thermal Analysis and Calorimetry, v. 71, n. 1, 2003. http://dx.doi.org/10.1023/A:1022234805054

SHAHIDI, F. Antioxidants: Extraction, Identification, Application and Efficacy Measurement. Eletronic Journal of Enviromental, Agricultural and Food Chemistry, v. 7, n. 8, p. 3325-3330, 2008.

SILVERSTEIN, R. M.; WEBSTER, F. X. Identificação espectrofotométria de compostos orgânicos. 6. ed. Rio de Janeiro: Livros Técnicos e Científicos, 2000.

TAHERIAN, A.; RAMASWAMY, H. Effects Of Added Weighting Agent And Xanthan Gum On Stability And Rheological Properties Of Beverage Cloud Emulsions Formulated Using Modified Starch. Journal of Food Process Engineering, v. 30, n. 2, p. 204-224, 2007. http://dx.doi.org/10.1111/j.1745-4530.2007.00109.x

U. S. FOOD AND DRUG ADMINISTRATION - FDA. Everything Added to Food in the United States. Washington: FDA, 2009. Disponível em: <http://www.fda.gov/Food/ FoodIngredientsPackaging/ucm115326.htm $>$.

VECCHIO, S. et al. Kinetic Study of Thermal Breakdown of Triglycerides Contained in Extra-Virgin Olive Oil. Journal of Thermal Analysis and Calorimetry, v. 91, n. 1, p. 51-56, 2008. http://dx.doi.org/10.1007/s10973-007-8373-4

YILMAZ, M. T.; KARAKAYA, M. Differential Scanning Calorimetry Analysis of Goat Fats: Comparison of Chemical Composition and Thermal Properties Differential Scanning Calorimetry Analysis of Goat Fats. Comparison of Chemical Composition and Thermal Properties, v. 86, n. 9, p. 877-883, 2009. http://dx.doi.org/10.1007/ s11746-009-1420-5 